\title{
UPAYA PENCEGAHAN KEBOCORAN DATA KONSUMEN MELALUI PENGESAHAN RUU PERLINDUNGAN DATA PRIBADI (STUDI KASUS E-COMMERCE BHINNEKA.COM)
}

\author{
Deanne Destriani Firmansyah Putri \\ Universitas Pembangunan Nasional Veteran Jakarta \\ Jalan RS. Fatmawati, Pondok Labu, Jakarta Selatan, DKI Jakarta, Indonesia \\ E-mail: deannedestrianifp@upnvj.ac.id \\ Muhammad Helmi Fahrozi \\ Universitas Pembangunan Nasional Veteran Jakarta \\ Jalan RS. Fatmawati, Pondok Labu, Jakarta Selatan, DKI Jakarta, Indonesia \\ E-mail: helmifakhrazi@upnvj.ac.id
}

\begin{abstract}
ABSTRAK
Kemajuan teknologi yang diiringi perkembangan internet kini kian pesat. Di era globalisasi seperti ini kita semakin dipermudah semenjak kemuncul internet. Seperti belanja, kita dapat membeli kebutuhan sehari-hari melalui aplikasi belanja online lewat beberapa e-commerce. Pelanggan e-commerce di Indonesia tercatat mengalami peningkatan sebesar 38,3\% setelah terjadi pandemi, hal ini justru membuat tingkat keamanan internet semakin rentan karena banyak pendaftar baru yang mendaftarkan data pribadinya ke dalam data pelanggan e-commerce. Maka tak banyak terjadi kasus kebocoran data seperti yang terjadi pada e-commerce Bhinneka.com. Oleh karena itu tentu kita masih dihadapi persoalan mengenai bagaimana pencegahan kebocoran data dan apa upaya penindakan untuk pelaku kebocoran data serta bagaimana tanggung jawab dari e-commerce tersebut, maka perlu adanya pengesahan RUU Perlindungan Data Pribadi yang mana telah dibentuk oleh pemerintah dari lama, RUU ini apabila disahkan dapat menjadi jawaban dari persoalan kebocoran data. Metode penelitian yang digunakan adalah yuridisnormatif dengan pendekatan perundang-undangan dan pendekatan kasus. Dalam penelitian ini akan menjabarkan betapa pentingnya RUU Perlindungan Data Pribadi untuk segera disahkan untuk menutut pelaku dan menuntut pertanggungjawaban pemilik e-commerce itu sendiri, tentunya masyrakat akan mendapatkan kepastian hukum untuk menangani masalah kebocoran data.
\end{abstract}

Kata Kunci: E-commerce; Kebocoran Data; Pandemi COVID-19; Perlindungan Data Pribadi.

\begin{abstract}
The progression of the technology which accompanied by development of the internet are growing rapidly. In this era of globalization, we've made it easier by the since emerged of the internet. Like shopping, we can buy our needs by online shopping application through some e-commerces. The consumers of e-commerce in Indonesia has increased until 38,3\% after this pandemic happened, this thing actually makes the level of internet security more vulnerable because many registrants just register their
\end{abstract}


data into the e-commerce. So many cases about data leakage, like it happened in ecommerce Bhinneka.com. Therefore, we still facing problems regarding about data leakage and how to prevent data leakage, what our behaviour regarding data leakage perpetrators and what the responsibility by the e-commerce, and then to legalization The Protection of Personal Data Bill is very important, if this bill has legalized it can answer all problems about data leakage. The research method used is normative juridical with statute approach and case approach. In this research will be explained how important to legalization The Protection of Personal Data Bill, because many important articles which can be applied to the consumers who feel disadvantaged by data leakage perpetrators and public will get legal certainty to deal with data leakage problems.

Keywords: Data Leakage; E-commerce; Pandemic of COVID-1; Personal Data Protection.

\section{A. PENDAHULUAN}

Perkembangan globalisasi yang semakin pesat ikut mendorong percepatan kemajuan teknonlogi. Kemajuan tersebut dapat kita rasakan sehari-sehari, seperti telfon genggam yang sering kita gunakan untuk berkomunikasi dengan sanak saudara yang jaraknya terlampau jauh. Kemajuan teknologi juga diiringi dengan penemun internet yang semakin memudahkan masyarakat, tak hanya Indonesia namun seluruh dunia ikut merasakan kemudahan semenjak adanya internet. Perkembangan internet semakin hari juga semakin dipercanggih dengan beberapa aplikasi-aplikasi yang sangat membantu memudahkan aktivitas banyak orang. Misalnya kemudahan akses perjalanan untuk memesan tiket kereta api, kita tidak perlu datang langsung ke stasiun untuk membli tiket ke kota tujuan. Dengan bantuan internet kita dapat memesannya hanya dari rumah. Begitu juga untuk belanja, mulai dari belanja untuk kebutuhan primer, kebutuhan sekunder sampai kebutuhan tersier. Semua kebutuhan tersebut dapat dibeli melalui perdagangan elektronik atau e-commerce.

Dengan bantuan internet kita dapat memesan kebutuhan apapun menjadi mudah. Hanya melalui telfon genggam kita yang canggih, kita dapat memesan barang yang ingin kita beli hanya dari rumah tanpa harus bertemu langsung dengan pedagangnya. Apalagi semenjak terjadinya pandemi COVID-19 pada awal bulan Maret, situasi ini mendorong para pedangan untuk menjual barang-barangnya secara online, dengan begitu pelanggan e-commerce juga meningkat. Setidaknya jumlah pelanggan e-commerce di Indonesia sejak bulan Januari hingga Juli 2020 
meningkat hingga 38,3 persen. ${ }^{1}$ Dengan begitu, banyak sekali masyarakat Indonesia yang mendaftarkan data pribadinya untuk bergabung dan berlangganan ke $e$ commerce yang dituju. Karena untuk menjadi pengguna dari e-commerce kita diharuskan mengisi sebuah formulir yang tertera di halaman suatu web dengan mengisi data pribadi secara umum. Tak hanya e-commerce, sistem elektronik milik perusahaan digital lain pun banyak yang meminta penggunanya untuk mendaftarkan data pribadi mereka, misalkan sistem elektronik dompet digital, aplikasi pencari teman, aplikasi pemesanan kendaraan, dan lain-lain, Tiap klasifikasi jenis sistem elektronik atau perusahaan digital memiliki hak untuk mengetahui data pribadi penggunanya.

Pendaftaran data pribadi ke dalam sistem elektronik tersebut membuat penggunaan sistem elektronik apapun termasuk e-commerce meningkat. Maka dari itu, hal ini menjadikan keamanan internet semakin rentan dan mudah disusup serta disalahgunakan oleh oknum jahat, maka tak banyak kita mendengar terjadinya kasus kebocoran data. Misalnya yang baru terjadi di bulan Mei 2020 kemarin, sebanyak sepuluh perusahaan digital mengalami kebocoran data dengan total hingga 73 juta lebih data bocor, termasuk e-commerce Bhinneka.com yang menjadi pendekatan kasus di dalam penelitian ini.

Sebanyak 1,2 juta pengguna e-commerce Bhinneka.com mengalami kebocoran data. Data pribadi pengguna e-commerce Bhinneka.com dijual secara bebas oleh sekelompok hacker di sebuah pasar web gelap dengan maksud dan tujuan untuk mendapat keuntungan dari hasil penjualan data tersebut. Tentu sangat bahaya apabila data pribadi kita sudah tersebar, karena dengan data pribadi di sana tercantum dengan jelas nama lengkap, jenis kelamin, agama, kewarganegaraan atau data pribadi yang dikombinasikan untuk mengidentifikasi seseorang. ${ }^{2}$ Menanggapi kejadian tersebut, kepala periklanan Bhinneka.com hanya menyarankan para penggunanya untuk selalu berhati-hati dalam mengisi data di dalam internet, mengganti password secara berskala dengan menggunakan password dengan kekuatan yang tinggi (mengkombinasikan dengan huruf, angka dan juga simbol), dan tidak menggunakan satu password yang sama untuk semua aplikasi terlebih lagi

1 Dewi Adhitya S. Koesno, "Jumlah Pelanggan E-Commerce Tercatat Meningkat 38,3\% Selama Pandemi," dalam https://tirto.id/jumlah-pelanggan-e-commerce-tercatat-meningkat-383-selamapandemi-f1eP Akses 18 Oktober 2020

2 RUU Perlindungan Data Pribadi 
aplikasi yang penting seperti mobile banking. ${ }^{3}$ Tentu kita harus memerhatikan halhal kecil seperti itu, karena tentu kasus kebocoran data ini tidak hanya terjadi pada e-commerce Bhinneka.com saja, tentu masih banyak e-commerce atau marketplace lain yang pernah mengalami kebocoran data.

Keterlibatan Pemerintah dalam menangani hal-hal di atas sangat dinanti. Melalui pengesahan RUU Perlindungan Data Pribadi diharapkan menjadi titik cerah bagi konsumen yang merasa dirugikan dari masalah kebocoran data pribadi. RUU Perlindungan Data Pribadi dirancang dengan maksud menjaga konsep hak privasi. Dalam Naskah Akademik RUU Perlindungan Data Pribadi pun mengatakan bahwa "hak privasi melalui perlindungan data pribadi merupakan elemen kunci bagi kebebasan dan harga diri individu," maka dari itu tujuan dibentuknya regulasi perlindungan data pribadi ini adalah untuk melindungi kepentingan konsumen dari penyalahgunaan data pribadi konsumen. Indonesia sendiri belum memiliki peraturan perundang-undangan yang jelas untuk mengatur perlindungan data pribadi, padahal tentu kita akan selalu dihadapi persoalan mengenai kebocoran data, maka pembentukan rancangan mengenai perlindungan data pribadi dapat dikatakan sebagai langkah yang tepat.

Sebelumnya, masalah terkait e-commerce ini sudah dibahas oleh Sandryones Palinggi dan Erich C. Limbongan dalam jurnalnya yang berjudul "Pengaruh Internet Terhadap Industri E-commerce dan Regulasi Perlindungan Data Pribadi Pelanggan di Indonesia" namun dalam tulisan tersebut yang menjadi pembeda dengan tulisan penulis sekarang adalah dalam tulisan milik Sandryones dan Erich hanya menekankan bahwa proses transaksi harus berpegang pada prinsip di dalam UU ITE dan RUU PDP, sedang di dalam penelitian ini lebih menjabarkan kasus spesifik untuk dianalisis sehingga masalah serupa diupayakan tidak akan terjadi lagi di kemudian hari dan juga mendorong pemerintah untuk mengesahkan RUU Perlindungan Data Pribadi sebagai upaya perlindungan konsumen.

Masalah-masalah terkait kebocoran data harus menjadi sorotan dan segera mendapat solusi yang pasti, sebab kemajuan teknologi dan internet akan selalu berkembang dan kejahatan akan selalu ada, tentu masyarakat butuh perlindungan agar terciptanya keamanan dan kenyamanan dalam penggunaan teknologi dan internet. Peningkatan sistem keamanan di dalam sistem elektronik juga harus

3 Roy Franedya, "1,2 Juta Data Pengguna Dikabarkan Bocor, Bhinneka Minta Maaf," dalam https://www.cnbcindonesia.com/tech/20200512164725-37-157971/12-juta-data-penggunadikabarkan-bocorbhinneka-minta-maaf Akses 18 Oktober 2020 
menjadi perhatian. Sehingga dalam hal ini konsumen akan memiliki perlindungan dan terpenuhinya hak konsumen akan perlindungan dalam berinternet atau bertransaksi di segala sistem elektronik khususnya e-commerce.

\section{B. METODE PENELITIAN}

Metode penelitian yang digunakan di dalam penulisan ini adalah penelitian secara yuridis normatif yaitu mengacu pada asas hukum dan juga peraturan perundang-undangan terkait dengan perlindungan konsumen dan perlindungan data konsumen serta perbandingan regulasi regulasi terlibat dalam penulisan (regulasi yang sudah disahkan maupun belum disahkan). Pendekatan masalah yang digunakan di dalam penelitian ini berupa pendekatan perundang-undangan (statute approach) dan juga menggunakan pendekatan kasus (case approach). Cara mengumpulkan data menggunakan metode studi pustaka (library research). Sumber data yang digunakan di dalam penelitian menggunakan data sekunder dengan meliputi tiga sumber bahan hukum, yaitu bahan hukum primer, bahan hukum sekunder dan bahan hukum tersier.

Bahan hukum primer merupakan bahan hukum yang mempunyai otoritas, bahan hukum yang dipakai dalam penelitian ini antara lain: Undang-Undang Nomor 11 Tahun 2008 Tentang Informasi dan Transaksi Elektronik, Peraturan Menteri Komunikasi dan Informatika Republik Indonesia Nomor 20 Tahun 2016, peraturan Pemerintah Republik Indonesia Nomor 71 Tahun 2019 dan Undang-Undang Nomor 8 Tahun 1999 Tentang Perlindungan Konsumen. Kemudian, bahan hukum sekunder yaitu bahan hukum yang membantu menjelaskan penjelasan mengenai bahan hukum primer, bahan hukum primer yang dipakai di dalam penelitian ini antara lain: RUU Perlindungan Data Pribadi, hasil penelitian terdahulu, buku teks, dan juga jurnal hukum yang sesuai dengan topik pembahasan. Terakhir, bahan hukum tersier, yaitu bahan hukum yang memberikan petunjuk maupun penjelasan terhadap bahan hukum primer dan bahan hukum sekunder, bahan hukum yang dipakai berupa Kamus Besar Bahasa Indonesia dan ensiklopedia.

\section{ANALISIS DAN PEMBAHASAN}

\section{Pengenalan Internet dan E-commerce di Indonesia dan Persoalan Kebocoran Data}

Kemunculan internet yang berfungsi untuk memudahkan manusia memang kehadirannya sudah dirasakan di tengah-tengah kehidupan kita. 
Mulai dari akses berbelanja harian, bulanan atau belanja barang mewah sekalipun sekarang bisa dilakukan hanya melalui internet. Perlu diakui bahwa memang kehadiran internet sangat membantu segala aspek, mulai dari bidang sosial, hukum sampai ekonomi. Khususnya ekonomi, banyak pelaku usaha mulai membuka usahanya menggunakan internet, segala transaksi jual-beli dilakukan secara online. Hadirnya internet mendorong pembentukan $e$ commerce yang mampu mendorong Usaha Mikro Kecil dan Menengah di berbagai wilayah untuk ikut serta memajukan usahanya. ${ }^{4}$ Mungkin untuk kebanyakan orang yang masih awam dengan internet akan bertanya-tanya mengenai e-commerce dan mengapa e-commerce dibilang sangat membantu para pelaku usaha juga meringan para konsumen untuk berbelanja.

E-commerce menurut Laudon J dan Laudon C didefinisikan sebagai "suatu proses membeli dan menjual produk-produk secara elektronik oleh konsumen dan dari perusahaan ke perusahaan dengan komputer sebagai perantara transaksi bisnis" (Laudon, J; Laudon, 1998). Keunggulan dari $e$ commerce itu sendiri adalah efisiensi. Pelaku usaha dapat memasarkan produknya hanya melalui katalog online, sehingga konsumen atau pembeli produk dapat membeli produk pilihannya hanya melalui website atau aplikasi dari e-commerce itu sendiri. Dan kemudian keunggulan lainnay adalah efektif. Pelaku usaha dapat bertransaksi secara online dengan konsumen atau calon pembeli hanya dengan internet, tidak perlu bertatap wajah atau bertemu langsung namun kegiatan jual-beli sudah bisa dilakukan dengan cepat sampai barang sampai dari tangan penjual ke tangan pembeli.

Di Indonesia, penggunaan internet meningkat semenjak terjadinya pandemi COVID-19 yang mulai muncul sejak pertengahan bulan Maret 2020. Hal ini dikarenakan banyak aktivitas yang dilakukan di rumah atas himbauan pemerintah untuk memutus mata rantai penyebaran COVID-19, mulai dari bekerja di rumah atau work from home maupun penyelenggaraan belajar mengajar dari tingkat sekolah dasar sampai bangku universitas, semua dilakukan secara daring atau online. Menurut Asosiasi Penyelenggara Jasa Internet Indonesia (APJII) saat ini sedang menghitung kembali pengguna internet di Indonesia, tetapi ketua umum APJII mengatakan bahwa trafik

4 Sandryones Palinggi dan Erich C. Limbongan, "Pengaruh Internet Terhadap Industri Ecommerce dan Regulasi Perlindungan Data Pribadi Pelanggan di Indonesia” (jurnal disampaikan pada Seminar Nasional Riset dan Teknologi (SEMNAS RISTEK) Jakarta, 27 Januari 2020, hal. 226 
penggunaan internet di Indonesia sampai Juni 2020 meningkat $20-25 \%$ dari sebelumnya, terdata bahwa setidaknya jumlah pengguna Internet di Indonesia pada 2018 mencapai 171,17 juta dari total populasi penduduk Idnonesia sebanyak 264,14 juta jiwa5 ${ }^{5}$, sampai dengan data terakhir bahwa pengguna internet di Indonesia dalam data terakhir bulan November 2020 mencapai 196,7 juta pengguna. ${ }^{6}$

Dari 196,7 juta pengguna internet tersebut banyak yang menggunakan internet hanya untuk sekadar menggunakan sosial media dan ada juga untuk menggunakan e-commerce, karena banyak ragam pengguna internet menggunakan internetnya tergantung dengan keperluan masing-masing. Data Bank Indonesia mengatakan bahwa transaksi e-commerce pada bulan Agustus 2020 naik hingga mencapai 140 juta dibandingkan pada tahun 2018 yaitu sebesar 40 juta $^{7}$, tentu peningkatan ini masih dilatarbelakangi akibat kemunculan COVID-19.

E-commerce di Indonesia sendiri sudah banyak. Tentu e-commerce yang sering kita dengar adalah TokoPedia, Shopee, Blibli.com, OLX, Bhinneka.com dan lain-lain. Sistematika dari penggunaan e-commerce ini adalah dengan cara mendaftarkan data diri kita terlebih dahulu ke dalam e-commerce tersebut untuk didaftarkan sebagai pengguna yang sah dan agar dapat melanjutkan transaksi jual-beli. Biasanya, di dalam pendaftaran penggunaan e-commerce akan ditanyakan nama panjang, tanggal, dan tahun lahir, dan tentu alamat. Hal ini utnuk memudahkan pendataan e-commerce untuk melihat penggunanya dan beberapa e-commerce tentu juga menyediakan dompet digital atau $e$ wallet untuk transaksi pembayarannya. Pengguna e-wallet ini hampir sama dengan mobile banking, tentu hanya kita si pemilik saja yang boleh mengetahui data-data di dalamnya, kecuali pemilik e-commerce sebagai pemegang database pengguna dan penyelenggara sistem elektronik. Di samping kemudahan-kemudahan ini, tentu kita harus memperhatikan isu lain

${ }^{5}$ Agus Tri Haryanto, "APJII Sebut Jumlah Pengguna Internet di Indonesia Naik Saat Pandemi," internet-di-indonesia-naik-saat-pandemi (diakses 30 Oktober 2020)

6 Dimas Jarot Bayu, "Jumlah Pengguna Internet di Indonesia Capai 196,7 juta," Databoks Katadata, $\quad$ https://databoks.katadata.co.id/datapublish/2020/11/11/jumlah-pengguna-internet-diindonesia-capai-1967-juta (diakses 19 Januari 2021)

${ }^{7}$ Antara dan Kodrat Setiawan, "Bank Indonesia: Transaksi E-Commerce Agustus 2020 Naik hingga Mencapai 140 Juta," Bisnis Tempo, https://bisnis.tempo.co/read/1398066/bank-indonesiatransaksi-e-commerce-agustus-2020-naik-hingga-mencapai-140-juta/full\&view=ok (diakses 30 Oktober 2020) 
dalam kegiatan belanja online, isu yang harus menjadi fokus untuk kita perhatikan adalah perlindungan data pribadi. Karena dalam aktivitas daring, data pribadi merupakan bagian yang sangat esensial karena hal ini berhubungan langsung dengan metode pembayaran, pemasaran maupun penawaran. 8

Data pribadi di dalam Pasal 1 Peraturan Pemerintah Nomor 71 Tahun 2019 tentang Penyelenggaraan Sistem dan Transaksi Elektronik diartikan sebagai, "Data Pribadi adalah setiap data tentang seserorang baik yang teridentifikasi dan/atau dapat diidentifikasi secara tersendiri atau dikombinasi dengan informasi lainnya baik secara langsung maupun tidak langsung melalui Sistem Elektronik/atau non-elektronik." Pengertian serupa juga tercantum di dalam Rancangan Undang-Undangan Perlindungan Data Pribadi, namun RUU Perlindungan Data Pribadi lebih membagi data pribadi menjadi dua sifat, yaitu data pribadi yang bersifat umum dan data pribadi yang bersifat spesifik. Untuk pencantuman nama lengkap, jenis kelamin, kewarganegaaran, agama dan/atau data pribadi yang mengidentifikasi pribadi seseorang masuk ke dalam data pribadi yang bersifat umum. Untuk secara spesifik maka data pribadi yang tercantum dapat meliputi kesehatan, data biometrik, data genetika, orientasi seksual, pandangan politik, catatan kejahatan, data anak, data keuangan pribadi, dan/atau data lainnya sesuai dengan ketentuan perundang-undangan.

Saat ini sedang maraknya terjadi kasus kebocoran data, peningkatan pengguna internet dan e-commerce yang kian meningkat semenjak terjadinya pandemi COVID-19 membuat sistem keamanan internet menjadi rentan. Banyak website yang diretas oleh oknum tidak bertanggung jawab, termasuk website e-commerce Bhinneka.com yang merupakan situs e-commerce Indonesia. Tak hanya Bhinneka.com, e-commerce besar lain yang ada di Indonesia pun juga pernah mengalami masalah kebocoran data, bahkan data pasien COVID-19 di Indonesia pun juga diduga mengalami kebocoran data. Berikut data-data bahwa kebocoran data di Indonesia memiliki banyak korban.

\section{Tabel 1. Jumlah Korban Kebocoran Data Yang Terjadi di Indonesia}




\begin{tabular}{|c|c|c|}
\hline Nama Data & Jumlah Data Yang Bocor & $\begin{array}{c}\text { Tanggal dan Tahun } \\
\text { Terjadinya Kebocoran } \\
\text { Data }\end{array}$ \\
\hline $\begin{array}{c}\text { Data Pasien COVID-19 } \\
\text { Indonesia }\end{array}$ & 230.000 & 20 Mei 2020 \\
\hline Data KPU Indonesia & 2.300 .000 & 21 Mei 2020 \\
\hline $\begin{array}{l}\text { Data Konsumen } \\
\text { Bhinneka.com }\end{array}$ & 1.200 .000 & 11 Mei 2020 \\
\hline Data Konsumen Bukalapak & 13.000 .000 & 5 Mei 2020 \\
\hline Data Konsumen Tokopedia & 91.000 .000 & 3 Mei 2020 \\
\hline Data Mahasiswa UNDIP & 125.000 & 5 Januari 2021 \\
\hline
\end{tabular}

Sumber: CNN Indonesia, 'Deretan Peristiwa Kebocoran Data Warga RI selama 2020 dan Liputan6.com, 'Lebih dari 125 Ribu Data Mahasiswa UNDIP Bocor'

Sebelumnya, Bhinneka.com website yang didirikan oleh Hendrik Tio, Nicholas, Johannes, Darsono dan Tommy pada tahun 1999 ini merupakan sebuah website yang memfokuskan bisnisnya pada bidang distribusi produk IT seperti PC Build Up dan Compatible Peripherals, rancang bangun perangkat lunak jasa jaringan (LAN/WAN), solusi video editing hingga pusat servis hingga pada akhirnya Bhinneka.com resmi untuk memutuskan memfokuskan penjualannya kepada keperluan bisnis jual-beli. ${ }^{9}$

Namun, bulan Mei 2020 kemarin, Bhinneka.com mengalam kasus kebocoran data, sebanyak 1,2 juta data pengguna Bhinneka.com dijual bebas oleh sekelompok hacker bernama ShinyHunter. Data pengguna Bhinneka.com dan 10 perusahaan lainnya yang serupa juga dijual bebas di sebuah pasar web gelap, sehingga tercatat setidaknya terdapat 73,2 juta data diri pengguna $e$ commerce dan data perusahaan lainnya terjual bebas dengan harga mencapai USD 18 ribu perdatanya. ${ }^{10}$ Bahkan, yang baru terjadi di awal tahun 2021 ini

9 Warta Ekonomi, “1,2 Juta Data Pengguna Diretas, Ini profil perusahaan Bhinneka.com yang Berdiri Sejak Tahun 1999, https://www.wartaekonomi.co.id/read285015/12-juta-dana-penggunadiretas-ini-profil-perusahaan-bhinnekacom-yang-berdiri-sejak-tahun-1999/0 (diakses pada 1 November 2020)

10 Ibid 
adalah terjadinya kebocoran data mahasiswa dari Universitas Diponegoro (UNDIP), sebanyak 125 ribu data mahasiswanya bocor.11 Melihat hal ini tentu harus menjadi perhatian besar bahwa sudah saatnya pengesahan RUU Perlindungan Data Pribadi harus dilakukan karena lemahnya negara kita dalam melindungi data pribadi masyarakatnya yang begitu privasi.

\section{Pengesahan RUU Perlindungan Data Pribadi Sebagai Solusi Kebocoran Data Konsumen}

Kemajuan teknologi dan perkembangan internet memang sangat besar pengaruhnya. Namun, tidak semua hal berdampak positif, di mana ada positif pasti ada negatif. Kita terkadang terlalu terlena dengan kecanggihan internet yang memudahkan kita, namun lupa bahwa dampak dari penyebaran data pribadi ke internet sangat berbahaya. Di mana ada proses jual-beli atau perpindahan tangan kepemilikan dari pelaku usaha ke tangan konsumen, pasti ada yang namanya perjanjian. Meskipun $e$ commerce sifatnya tidak bertatap wajah, maka perjanjian yang dilakukan adalah secara elektronik. Biasanya, setelah kita mengisi data diri di dalam aplikasi e-commerce, maka aplikasi e-commerce akan menjabarkan perjanjian antara pengguna aplikasi/konsumennya di suatu halaman web, di dalam perjanjian tersebut telah dijabarkan sendiri oleh e-commerce-nya, kita sebagai pengguna hanya disediakan sebuah kolom untuk dicentang sebagai persetujuan, apakah kita sepakat dengan perjanjian yang tertera atau tidak. Maka, tidak adanya peran kita sebagai pengguna untuk ikut andil dalam menyusun perjanjian. Maka dari itu, hal ini bisa dikatakan bahaya untuk mendaftarkan diri kita ke internet. Apabila tidak teliti membaca perjanjiannya maka bisa menjadi boomerang sendiri untuk kita.

Perjanjian elektronik ini bisa disebut sebagai perjanjian klausula baku, menurut Sudaryatmo (Sudaryatmo, 1999) ia menjelaskan bahwa "karakteristik klasula baku yaitu: Perjanjian dibuat secara sepihak oleh mereka yang posisinya relatif lebih kuat dari konsumen." Dalam perjanjian pendaftaran data pribadi di dalam e-commerce, pihak yang relatif lebih kuat dari konsumen adalah pihak e-commerce sebagai pemegang data. Kemudian karakteristik lainnya adalah "konsumen sama sekali tidak dilibatkan dalam menentukan isi perjanjian." Tentu hal ini sangat sesuai dengan perjanjian elektronik yang mana konsumen tidak dilibatkan namun konsumen

11 Liputan6, "Lebih dari 125 Ribu Data Mahasiswa UNDIP Bocor," https://www.liputan6.com/tekno/read/4449390/lebih-dari-125-ribu-data-mahasiswa-undip-bocor (diakses 23 Januari 2021 
terpaksa menerima perjanjian elektronik ini karena adanya rasa butuh konsumen terhadap e-commerce tujuan.

Meskipun perjanjian dilakukan secara elektronik, tetapi akan tetap tercantum pula cara penyelesaian sengketanya seperti perjanjian tulis tatap muka pada umumnya. Menurut Subekti, perjanjian dianggap sah apabila memenuhi syarat subyektif dan obyektif dan perjanjian juga mengikat para pihak mengenai hak dan kewajibannya. $^{12}$ Maka dari itu, apabila terjadi kebocoran data yang dapat mengakibatkan kerugian bagi pengguna e-commerce itu sendiri, harus ada pertanggungjawaban pemerintah kepada pelaku dan pertanggungjawaban dari pemilik e-commerce kepada para konsumennya. Namun, Indonesia sendiri mengenai regulasi tentang perlindungan konsumen terhadap kebocoran data e-commerce belum terlalu memberikan perhatian lebih, belum ada undang-undang yang mengaturnya secara khusus. Regulasi mengenai perlindungan data pribadinya pun belum disahkan, saat ini Indonesia dalam menangani kasus kebocoran data yang terjadi pada $e$ commerce masih berpegang teguh pada Undang-Undang Nomor 11 Tahun 2008 tentang Informasi dan Transaksi Elektronik sebagaimana telah diubah dengan Undang-Undang Nomor 19 Tahun 2016 dan juga Peraturan Pemerintah Nomor 71 Tahun 2019 tentang Penyelenggaraan Sistem dan Transaksi Elektronik.

Dalam UU ITE perbuatan yang dilarang yang menyangkut kebocoran data pribadi tercantum di dalam Pasal 27 ayat (1) yang mengatakan bahwa, "Setiap Orang dengan sengaja dan tanpa hak mendistribuksikan dan/atau mentransmisikan dan/atau membuat dapat diaksesnya Informasi Elektronik dan/atau Dokumen Elektronik yang memiliki muatan yang melanggar kesusilaan." Hal ini belum menjelaskan secara penuh unsur yang dirugikan adalah mengenai kebocoran data pribadi, maka dasar hukumnya tidak terlalu kuat untuk menjerat masalah kebocoran data konsumen yang terjadi di kebanyakan e-commerce di Indonesia.

Sudah menjadi kewajiban negara untuk melindungi masyarakatnya, dalam alinea keempat pembukaan Undang-Undang Dasar Republik Indonesia pun sudah jelas dikatakan bahwa pemerintah Republik Indonesia wajib melindungi segenap bangsa dan di dalam Undang-Undang Nomor 29 Tahun 1999 tentang Hak Asasi Manusia Pasal 29 ayat (1) pun menyatakan bahwa "Setiap orang berhak mendapat perlindungan diri pribadi..." Memang di dalam Pasal dan Ayat tersebut tidak dijelaskan perlindungan diri seperti apa, namun dapat ditarik kesimpulan bahwa perlindungan data pribadi juga

12 Subekti. Pokok-Pokok Hukum Perdata (Jakarta: 2001) 
termasuk hak seseorang untuk merahasiakan segala hal di dalam dirinya yang bersifat pribadi atau biasa disebut sebagai perlindungan diri dari hak privasi. ${ }^{13}$

Data pribadi juga termasuk hal yang harus dilindungi karena data pribadi meliputi hak privasi dari masyarakat Indonesia itu sendiri. Secara luas privasi dibagi menjadi beberapa golongan ${ }^{14}$, namun yang paling masuk ke dalam kasus kebocoran data pribadi yang lebih berhubungan kepada teknologi dan internet yaitu mengenai privasi atas informasi yang menyanngkut dan berkaitan dengan cara pengumpulan informasi mengenai data pribadi, misal seperti informasi profil diri, informasi kredit dan catatan kesehatan, karena informasi-informasi seperti tersebut dapat diretas melalui internet.

Pengesahan RUU Perlindungan Data Pribadi harus segera disahkan dalam rangka memberikan kepastian hukum kepada pengguna atau konsumen e-commerce yang merasa dirugikan akibat dari kebocoran data pribadi. Urgensi dari pengesahan RUU Perlindungan Data Pribadi ini pun disampaikan oleh Menteri Komunikasi dan Informatika Johnny G. Plate karena tentu di dalam Undang-Undang ini nantinya akan mengatur hak dan kewajiban pemilik data, pemegang data sampai pemrosesan data. ${ }^{15}$ Maka tak heran apabila Kemkominfo terus mendesak percepatan pengesahan RUU Perlindungan Data Pribadi, karena didasari dengan ketakutan akan terjadinya kasus kebocoran data yang semakin banyak terjadi lagi di kemudian hari.

Di dalam Naskah Akademik RUU Perlindungan Data Pribadi yang diterbitkan oleh Kemkominfo melalui website BPHN mengutip Pasal 5 UU. 12 Tahun 2001 tentang Pembentukan Peraturan Perundang-Undangan perlu dilakukan asas pembentukan peraturan perundang-undangan yang baik. Maka dalam hal ini bentuk analisis dari asas pembentukan peraturan perundang-undangan yang baik agar RUU Perlindungan Data Pribadi dapat diterima masyarakat, menghasilkan analisis sebagai berikut:

a. “Kejelasan tujuan, bahwa setiap pembentukan peraturan perundangundangan harus ada kejelasan yang hendak dicapai."

Dalam pembentukan peraturan perundang-undangan perlindungan data pribadi sudah jelas tujuan yang hendak dicapai adalah untuk melindungi data pribadi masyarakat Indonesia dan melindungi hak privasinya.

\footnotetext{
13 I Dewa Gede Adi Wiranjaya dan I Gede Putra Ariana, "Perlindungan Hukum Terhadap Pelanggaran Privasi Konsumen Dalam Bertransaksi Online," Kerta Semaya, Vol. 4 No. 4 (2016) hal. 3

${ }_{14}$ Naskah Akademik RUU Perlindungan Data Pribadi yang mengutip melalui buku Abu Bakar Munir et.al, Privacy and Data Protection. (Malaysia Sweet \& Maxwell 2002)

${ }^{15}$ Akbar Evandio, "Kominfo Harap RUU Perlindungan Data Pribadi Disahkan Awal 2021," Bisnis https://teknologi.bisnis.com/read/20201230/101/1337114/kominfo-harap-ruu-perlindungan-datapribadi-disahkan-awal-2021 (diakses 23 Januari 2021)
} 
b. "Peraturan perundang-undangan harus dibentuk oleh lembaga yang berwenang."

Untuk itu dimohonkan kepada DPR atau lembaga pemerintah yang berwenang dalam pembentukkan undang-undang untuk segera mengesahkan RUU Perlindungan Data Pribadi.

c. "Dapat dilaksanakan, bahwa setiap pembentukan peraturan perundangundangan harus memperhitungkan efektivitas peraturan perundangundangan tersebut di dalam masyarakat, baik secara filosofis, sosiologis, maupun yuridis."

Efektivitas perundang-undangan Perlindungan Data Pribadi apabila disahkan akan memberikan bantuan kepada masyarakat secara yuridis, karena masyarakat yang merasa dirugikan atas kebocoran data pribadinya dapat melaporkan kejadiannya kepada pengadilan agar dapat diproses, dapat meminta pertanggung jawaban kepada pemilik e-commerce yang diduga terjadi kebocoran data dan meminta pemerintah untuk menindaklanjuti pelaku kebocoran data.

d. "Kedayagunaan dan kehasilgunaan, bahwa setiap peraturan perundangundangan dibuat karena memang benar-benar dibutuhkan dan bermanfaat dalam mengatur kehidupan bermasyarakat, berbangsa dan bernegara."

UU Perlindungan Data Pribadi akan menjadi undang-undang yang dibutuhkan oleh masyarakat, terlebih lagi proses perkembangan teknologi dan internet kian hari semakin dipercanggih. Kerentanan sistem keamanan internet juga ikut berkembang, tidak ada yang bisa menduga bahwa kapan kebocoran data akan terjadi. Maka disahkannya RUU Perlindungan Data Pribadi menjadi hal yang sangat dinanti.

Maka, dari analisis-analisis di atas dapat dilihat bahwa pengesahan RUU Perlindungan Data Pribadi dapat dikatakan menjadi solusi pencegahan kebocoran data. Selain itu, masyarakat Indonesia akan mendapatkan kepastian hukum. UndangUndang Nomor 8 Tahun 1999 Tentang Perlindungan Konsumen juga menuliskan sembilan hak konsumen, namun hak yang paling mengikat dengan permasalahan kebocoran data adalah hak kelima yang tertulis, "Hak untuk mendapat advokasi, perlindungan dan upaya penyelesaian sengketa perlindungan konsumen secara patut." Tidak dijelaskan secara tersirat, namun perlindungan yang dapat dimiliki konsumen dalah termasuk perlindungan terkait data pribadi yang terdaftar di dalam e-commerce tujuan. 
Hal-hal yang dilarang di dalam RUU Perlindungan Data Pribadi dijelaskan di dalam Pasal 51 ayat (1), ayat (2), dan ayat (3) yang mengatakan bahwa, "Setiap orang dilarang memperoleh atau mengumpulkan data pribadi untuk kepentingan pribadi yang dilakukan secara melawan hukum untuk mengungkapkan data pribadi dan juga menggunakan data pribadi yang bukan miliknya..." Sudah jelas bahwa di dalam RUU Perlindungan Data Pribadi ini jelas dikatakan larangan-larangan yang tidak boleh dilakukan setiap orang atau individu yang tunduk pada hukum ini untuk melakukan perbuatan yang jelas-jelas telah dilarang di dalam pasal dan ayat tersebut.

Ketiga ayat tersebut sangat ditujukan kepada pelaku pembocoran data pribadi pengguna e-commerce di Indonesia khususnya e-commerce Bhinneka.com yang mengalami kebocoran data sebanyak 1,2 juta pengguna. Pelaku pembocoran data pribadi melakukan aksinya tentu semata-mata untuk menguntungkan dirinya sendiri dan itu dilarang di dalam Pasal 51 RUU Perlindungan Data Pribadi. Dan untuk yang melanggar Pasal 51, maka ketentuan pidananya juga sudah ditentukan di dalam Pasal 61 ayat (1), ayat (2), dan ayat (3) RUU Perlindungan Data Pribadi. Pasal 61 dan ketiga ayat tersebut mengatakan bahwa "Pelaku pengumpulan data pribadi untuk mencari keuntungan dapat dipidana dengan pidana penjara paling lama 5 (lima) tahun atau pidana denda sebesar Rp 50 miliar, untuk pelaku pengungkapan data pribadi yang bukan miliknya dapat dipidana dengan pidana penjara paling lama 2 (dua) tahun atau pidana denda sebesar Rp 20 miliar dan bagi pelaku yang menggunakan data pribadi yang bukan miliknya maka dapat dijatuhkan pidana dengan pidana penjara paling lama 7 (tujuh) tahun dan pidana denda sebesar Rp 70 miliar."

\section{Upaya Pemerintah Dalam Menindak Pelaku Kebocoran Data dan Pertanggungjawaban Semua Aspek Yang Terlibat}

Meningkatnya jumlah penggunaan internet memungkinkan pula meningkatnya kejahatan siber. Dalam data Laporan Kasus Kejahatan Siber Indonesia yang bersumber dari Kepolisian Republik Indonesia (POLRI) kemudian dirangkum oleh Databoks Katadata dari bulan Januari-September 2020, setidaknya tercatat 18 laporan mengenai kasus peretasan sistem elektronik, 39 kasus pencurian data dan 71 kasus manipulasi data. ${ }^{16}$

${ }^{16}$ Cindy Mutia Annur, "Daftar Kejahatan Siber yang Paling banyak Dilaporkan ke Polisi," dalam https://databoks.katadata.co.id/datapublish/2020/09/08/daftar-kejahatan-siber-yang-paling-banyakdilaporkan-ke-polisi akses pada 4 November 2020 


\section{Tabel Grafik 2. Jumlah Kasus Kejahatan Siber di Indonesia per-}

Januari-September 2020

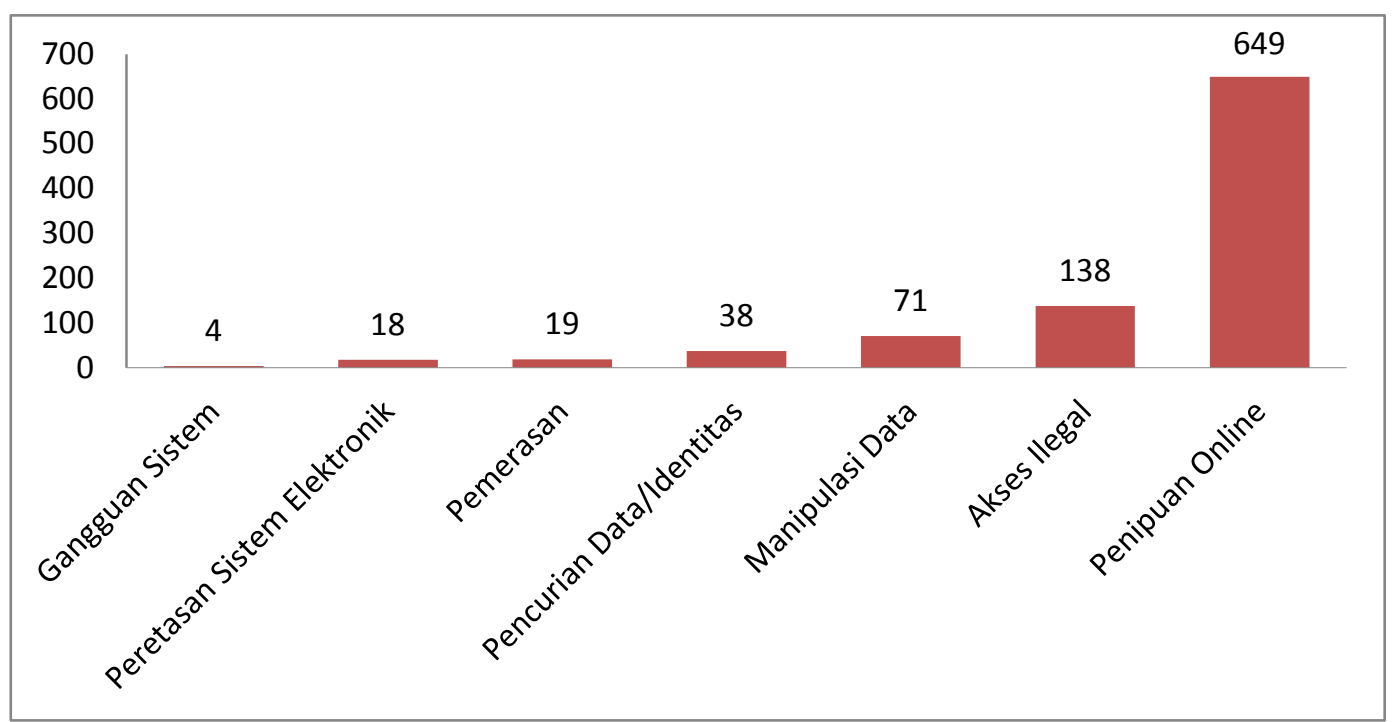

Sumber: Kepolisian Republik Indonesia September 2020

Jika tidak ada pergerakkan untuk mengesahkan RUU Perlindungan Data Pribadi, maka kemungkinan besar kejahatan yang tercantum di dalam datadata di atas dikhawatirkan akan semakin terus meningkat. Kejahatan akan selalu ada, bahkan kejahatan baru pun akan selalu muncul setiap harinya. Bila dilihat ke belakang, pasti ada beberapa alasan yang mendorong mengapa banyak orang yang nekat melakukan kejahatan siber, dorongan tersebut sudah pasti karena ada beberapa faktor yang mendukung untuk melakukan hal tersebut.

Kejahatan siber tentu dapat merugikan perorangan, kelompok bahkan satu negara. Kerugian tersebut pun tertuju pada kerugian bidang ekonomi, perbankan, politik bahkan bisa tertuju pada kerugian keamanan nasional. ${ }^{17}$ Kerugian keamanan nasional ini juga bisa mengusik ideologi Pancasila Indonesia, untuk mengatasi ancaman dan kerugian yang diakibatkan oleh kejahatan siber ini maka pemerintah perlu bersaing dengan laju percepatan teknologi yang kian massif dalam beberapa tahun ke belakang. ${ }^{18}$ Sehingga

17 Barda Nawawi Arief. Tindak Pidana Mayantara Perkembangan Kajian Cyber Crime di Indonesia. (Jakarta: PT Raja Grafindo, 2006) hal. 52

18 Wicipto Setiadi, Iwan Joesoef Erar, Muhammad Helmi Fahrozi 2020, "Pemberdayaan Masyarakat Dalam Mengimplementasikan Nilai Pancasila Untuk Menghadapi Globalisasi dan Era Industri 4.0" Jurnal Papatung, Vol. 3, No. 1, hal. 63 
dapat dilihat bahwa faktor-faktor yang mendorong salah satunya adalah faktor ekonomi, adanya rasa keinginan pelaku untuk memperoleh untuk dirinya sendiri dengan melakukan kejahatan siber, karena tak sedikit hasil penjualan data pribadi yang melakukan kejahatan pembocoran data lalu menjual data pribadi hasil retasan tersebut ke pasar web gelap dan mendapat keuntungan yang lumayan besar. Selain adanya dorongan faktor ekonomi, juga dilihat karena kurangnya aparat penegak hukum untuk lebih sigap dalam menangani pelaku kejahatan siber, unutk itu diperlukan kualitas aparat penegak hukum agar dapat menangani berbagai tindak kejahatan siber atau dugaan adanya tindak pidana kejahatan siber yang saat ini kian marak terjadi dan akan terus berkembang seiring berjalannya waktu dan perkembangan teknologi serta internet yang semakin canggih. ${ }^{19}$

Jika semua masalah harus ditemukan solusi, maka pertanggungjawaban merupakan salah satu solusinya. Bagi pihak pemilik data pribadi maka harus bertanggung jawab atas data yang diberikan sudah benar dan sesuai dengan data pribadinya sendiri bukan data pribadi orang lain, sedangkan tangguung jawab dari pemegang data pribadi orang lain yaitu harus bertanggung jawab untuk melindungi data pribadi milik orang lain, bertanggung jawab terhadap pengamanan dan perlindungan sarana dan prasarana Sistem Elektronik. ${ }^{20}$ Dalam pasal 21 Undang-Undang Nomor 39 Tahun 1999 tentang Hak Asasi Manusia menjelaskan bahwa "setiap orang berhak atas keutuhan pribadi, baik rohani maupun jasmani," dan karena itu maka tidak boleh menjadi obyek penelitian tanpa persetujuan. Diperjelas lagi bahwa yang dimaksud obyek penelitian di dalam pasal tersebut adalah "kegiatan yang menempatkan seseorang sebagai yang dimintai komentar, pendapat atau keterangan yang menyangkut kehidupan pribadi dan data-data pribadinya serta direkam gambar dan suaranya." Untuk itu harus adanya persetujuan terlebih dahulu dai pemilik data untuk menggunakan datanya, sedangkan kebocoran data pribadi yang marak terjadi adalah tanpa persetujuan dari pemilik data pribadi, maka dari itu perlu adanya Undang-Undang yang mengatur mengenai permasalahan ini.

20 Peraturan Pemerintah No. 71 Tahun 2018 Tentang Penyelengaraan Sistem dan Transaksi Elektronik Pasal 32 
Pengesahan sebuah Rancangan Undang-Undang memang tidak mudah, butuh banyak proses panjang sebelum dijadikan sebagai Undang-Undang yang sah yang isinya dapat dijalankan, salah satu prosesnya yaitu proses pengharmonisan. Padma Widyantari dan Adi Sulisiyono dalam tulisannya menjelaskan bahwa "Pengharmonisan merupakan upaya untuk menyelaraskan suatu peraturan perundang-undangan dengan peraturan perundang-undangan lainnya di dalam hierarki peraturan perundangundangan. (Sulistiyono Padma, 2020). Namun pengesahan RUU PDP ini sangat penting untuk kebanyakan masyarakat, apalagi zaman sekarang perkembangan teknologi yang diiringi dengan perkembangan internet semakin pesat dan canggih. Maka pertanggungjawaban yang diharapkan dari pemerintah adalah dengan cara mengesahkan RUU Perlindungan Data Pribadi.

Mengenai pembentukan Rancangan Undang-Undang, pemerintah tidak senantiasa menciptakan undang-undang tanpa alasan dan latar belakang yang jelas. Bila kedua hal tersebut sudah diketahui maka perlulah kita perhatikan kemanfaatan dari Rancangan Undang-Undang tersebut bila disahkan menjadi Undang-Undang dan kemudian isinya dapat dijalankan oleh penegak hukum dan juga masyarakat. Menurut Satjipto Rahardjo, beli mengatakan bahwa "Kemanfaatan hukum bisa dilihat sebagai perlengkapan masyarakat untuk menciptakan ketertiban dan keteraturan. Pada dasarnya peraturan hukum yang mendatangkan kemanfaatan hukum itu akan menciptkan ketenteraman dalam bermasyarakat." (Satjipto Rahardjo, 1991). Kemanfaatan dari Rancangan Undang-Undang Perlindungan Data Pribadi ini adalah mengenai masalah keamanan masyarakat dalam melakukan proses pengisian data yang mana di zaman sekarang proses pengisian tersebut dapat dilakukan secara dalam jaringan, bila RUU ini disahkan maka perlindungan serta ketenteraman masyarakat dari kemanfaatan Undang-Undang ini pun dapat dirasakan.

Di dalam Rancangan Undang-Undang Perlindungan Data Pribadi pun dijelaskan bahwa adanya asas pertanggungjawaban yang dimaksud di dalam RUU tersebut adalah agar adanya tindakan yang dilakukan secara tanggung jawab dari pihak penyelenggara data yang melalukan pemrosesan serta pengawasan data pribadi dan juga agar terjaminnya keseimbangan hak dan kewajiban pemilik data priabdi maupun pihak yang terkait. ${ }^{21}$ Pemerintah secara Umum

21 RUU Perlindungan Data Pribadi, Rancangan Penjelasan Tentang Perlindungan Data Pribadi 
harus mengesahkan Rancangan Undang-Undang Perlindungan Data Pribadi, pengesahan RUU PDP ini bisa termasuk tanggung jawab yang dapat diberikan oleh pemerintah, karena RUU PDP akan menjamin perlindungan terhadap pemilik data pribadi. Pemerintah juga dapat mengupayakan penindakan terhadap pelaku kebocoran data dengan memberikan sanksi pidana sesuai dengan Bab XIII dalam Rancangan Undang-Undang Perlindungan Data Pribadi mengenai Ketentuan Pidana yang sudah dijabarkan pada sub bab sebelumnya.

Sanksi tersebut diharapkan menjadi efek jera bagi para pelaku kebocoran data dan juga untuk korban dari kebocoran data akan mendapatkan kepastia hukum untuk melaporkan permasalahannya agar diselesaikan oleh aparat penegak hukum sesuai dengan hukum yang berlangsung, sehingga ada dasar hukum yang menguatkan bagi para pelapor maupun korban kebocoran data pribadi dan pemilik e-commerce sebagai pengelola data pribadi milik pengguna e-commerce-nya harus bertanggung jawab mengelola data pribadi sesuai dengan prinsip-prinsip pengelolaan data pribadi. Besar upaya pemerintah yang diharapkan adalah pengesahan RUU Perlindungan Data Pribadi terlebih dahulum karena jika RUU tersebut sudah disahkan menjadi Undang-Undang yang sah, maka aparat penegak hukum dan badan pemerintahan lainnya yang memiliki kewenangan terhadap perlindungan data pribadi dapat menindaklanjuti pelaku kebocoran data sesuai dengan hukum yang berlangsung.

\section{Kesesuaian Muatan Materi RUU Perlindungan Data Pribadi dengan Prinsip Perlindungan Konsumen}

Dalam bukunya, Celina Tri Siwi Kristiyanti (Kristiyanti, 2011) menjelaskan beberapa prinsip-prinsip perlindungan konsumen, prinsip-prinsip tersebut lebih ke arah tanggung jawab yang dapat dibedakan dengan beberapa jenis tanggung jawabnya, Kristiyanti maka menjabarkan beberapa prinsip itu dan mengatakan bahwa prinsipprinsip tersebut antara lain "Prinsip tanggung jawab berdasarkan unsur kesalahan, prinsip praduga untuk selalu bertanggung jawab, prinsip praduga untuk tidak selalu bertanggung jawab, prinsip tanggung jawab mutlak, dan prinsip tanggung jawab dengan batasan."

Namun, dilihat dari banyaknya kasus akan kebocoran data, bagi mereka yang merasa dirugikan akan menggugat pemegang dan pengendali data yaitu e-commerce yang perusahaannnya meminta para konsumen untuk mengisi data pribadi ke dalam sistemnya sebagai pembuktian bahwa konsumen tersebut benar-benar ingin 
menggunakan e-commerce-nya. Dalam hal ini prinsip tanggung jawab perlindungan konsumen yang bisa diterapkan adalah prinsip praduga untuk selalu bertanggung jawab, yaitu e-commerce yang menjadi tergugat atas gugatan dari para konsumen atau penggugat yang merasa dirugikan karena kebocoran data yang terjadi, selalu dianggap bertanggung jawab sampai tergugat tersebut dinyakan tidak bersalah atas pembuktian-pembuktian yang menguatkan.

Di dalam Naskah Akademik RUU Perlindungan Data Pribadi juga terdapat asas yang relevan mengnai perlindungan data pribadi, asas tersebut adalah asas pertanggungjawaban yang mengatakan bahwa "Pihak yang terkait persoalan mengenai pemrosesan data, penyebarluasan data, pengelolaan sampai pengawasan data pribadi harus bertindak secara bertanggung jawab". Bertanggung jawab yang dimaksud adalah sesuai dengan prinsip-prinsip pengelolaan data pribadi dan prinsip tanggung jawab perlindungan konsumen.

Tentu muatan materi di dalam RUU Perlindungan Data Pribadi ini sudah sesuai dengan prinsip perlindungan konsumen, karena konsumen di zaman era modern seperti ini sudah dipermudah menggunakan bantuan aplikasi $e$-commerce. Kebanyakan dari mereka harus mendaftarkan data pribadinya sebagai bukti pengguna dari $e$ commerce itu sendiri, tentu pendaftaran pribadi ini akan menimbulkan kekhawatiran bagi para konsumen bahwa data pribadinya akan digunakan atau bahkan diperjualbelikan tanpa persetujuan mereka.

Dalam materi muatan di RUU Perlindungan Data Pribadi ini juga terdapat hak dari pemilik data pribadi untuk menuntut dan menerima ganti rugi atas pelanggaran hak yang dilakukan oleh seseorang terhadap hak-haknya, di dalam perlindungan konsumen pun tiap konsumen juga berhak menuntut ganti rugi dan menerima ganti rugi atau kompensasi tersebut atas kerugian yang ditimbulkan seseorang terhadapnya.

\section{KESIMPULAN}

Pengesahan RUU Perlindungan Data Pribadi dapat dikatakan sebagai solusi kebocoran data pribadi konsumen terutama konsumen e-commerce yang mana pendaftaran pengunaan e-commerce mengharuskan mengisi data-data yang menyinggung data pribadi, yang mana hal ini akan sering kita temui di dalam internet. Semenjak kemunculan COVID-19 membuat peningkatan penggunaan internet naik. Hal tersebut justru membuat sistem keamanan internet semakin rentan dan mudah disusupi oleh oknum jahat untuk melakukan peretasan dan kebocoran data. Dengan pengesahan RUU Perlindungan Data Pribadi diharapkan dapat menjadi solusi kebocoran data pribadi karena korban atau pelaporan kebocoran data memiliki kepastian hukum dan memiliki dasar hukum yang jelas untuk melaporkan 
permasalahannya ke aparat penegak hukum agar korban ditindaklanjuti. Pemerintah memiliki tanggung jawab untuk melindungi hak masyarakatnya termasuk hak privasi mengenai data pribadi, untuk itu diharapkan melalui penulisan ini pemerintah khususnya DPR sebagai lembaga yang berwenang menyusun perundang-undangan dapat mengesahkan RUU Perlindungan Data Pribadi karena jika Rancangan Undang-Undang ini sudah menjadi Undang-Undang yang sah, pemerintah dan juga aparat penegak hukum serta lembaga pemerintah lainnya yang berwenang seperti Kementerian Kominfo, Badan Perlindungan Konsumen Nasional, Kementerian Perdagangan, Polri serta Badan Siber dan Sandi Negara memiliki landasan dan dasar hukum untuk menindaklanjuti pelaku kebocoran data sehingga pengguna e-commerce dapat merasa terlindungi dan merasakan keamanan dan kenyamanan dalam berinternet.

Adanya kesamaan dan kesesuaian materi muatan di dalam RUU Perlindungan Data Pribadi ini dengan prinsip perlindungan konsumen memberikan nilai tambah dan sangat yakin bahwa RUU PDP ini perlu disahkan agar menjadi solusi bagi para konsumen yang merasa dirugikan. Karena tiap konsumen memiliki hak untuk mendapatkan ganti rugi atau kompensasi, begitu juga di dalam muatan materi RUU Perlindungan Data Pribadi, di dalamnya mengatakan bahwa pemegang data memiliki hak untuk mendapatkan ganti rugi atas kerugian yang ditimbulkan dari pelanggaran hak-haknya. Pemegang data pribadi di sini termasuk konsumen. Karena konsumen termasuk pemilik data pribadi yang mana dapat mendaftarkan data pribadinya ke dalam sebuah e-commerce yang merupakan wadah bagi para konsumen untuk melukan transaksi jual beli keperluan sehari-harinya.

\section{REFERENCES}

\section{Peraturan Perundang-Undangan}

Republik Indonesia, Peraturan Menteri Komunikasi dan Informatika Nomor 20 tahun 2016 tentang Perlindungan Data Pribadi Dalam Sistem Elektronik

Republik Indonesia, Peraturan Pemerintah Nomor 71 tahun 2019 Tentang Penyelenggaraan Sistem dan Transaksi Elektronik

Republik Indonesia, Undang-Undang Nomor 28 tahun 2011 Tentang Informasi dan Transaksi Elektronik

Republik Indonesia, Undang-Undang Nomor 39 tahun 1999 Tentang Hak Asasi Manusia 
Republik Indonesiam Undang-Undang Nomor 8 tahun 1999 Tentang Perlindungan Konsumen

\section{Buku}

Arief, Barda Nawawi. 2006. Tindak Pidana Mayantara Perkembangan Kajian Cyber Crime di Indonesia. Jakarta: PT Raja Grafindo

Kenneth, Laudon dan Laudon Jane. 2007. Management Information System. Jakarta: Salemba Empat 2007

Kristiyanti, C. T. S. (2011). Hukum Perlindungan Konsumen. Sinar Grafika.

Miru, Ahmadi dan Sutarman Yodo (2011). Hukum Perlindungan Konsumen. Jakarta: Raja Grafindo Persada

Laudon, J; Laudon, K. C. (1998). Essential of Management Information System. Prentice Hall.

Satjipto Rahardjo. (1991). Ilmu Hukum. Alumni.

Subekti (2001) Pokok-Pokok Hukum Perdata. Jakarta: Intermasa

Sudaryatmo. (1999). Hukum dan Advokasi Konsumen. Citra Aditya Bakti.

Widjaja, Gunawan dan Ahmad Yani (2003) Hukum Tentang Perlindungan Konsumen. Jakarta: PT Gramedia Pustaka Utama

Zulham (2013) Hukum Perlindungan Konsumen. Jakarta: Kencana Prenada Media Group

\section{Jurnal}

Ana Maria F. Pasaribu. 2017. "Kejahatan Siber Sebagai Dampak Negatif Dari Perkembangan Teknologi Dan Internet Di Indonesia Berdasarkan Undang-Undang No. 19 Tahun 2016 Perubahan Atas Undang-Undang No. 11 Tahun 2008 Tentang Informasi Dan Transaksi Elektronik Dan Persfektif Hukum Pidana". Skripsi. Fakultas Hukum, Universitas Sumatera Utara, Medan.

Anak Agung Gede Mahardika Geriya, Ida Bagus Putu Sutama dan I Made Dedy Priyano, "Implementasi Undang-Undang Nomor 8 Tahun 1999 Tentang Perlindungan Konsumen Terhadap Jual Beli Online (E-Commerce) di BPSK Denpasar", Kertha 
Wicara, Volume 5, Nomor 1 Februari 2016

I Dewa Gede Adi Wiranjaya dan I Gede Putra Ariana, "Perlindungan Hukum Terhadap Pelanggaran Konsumen dalam Bertransaksi Online", Kertha Semaya: Journal Ilmu Hukum, Volume 6, No. 12017

Masitoh Indriyani, Nilam Andaria K.S, dan Satria Unggul W.P, "Perlindungan Privasi Data Pribadi Konsumen Daring Pada Online Marketplace System", Justitia Jurnal Hukum, Volume 1 No. 2 Oktober 2017, hal. 191-208

Mega Lois Aprilia dan Endang Prasetyawati, "Perlindungan Hukum Terhadap Data Pribadi Konsumen Pengguna Gojek", Mimbar Keadilan Jurnal Ilmu Hukum. Surabaya: Universitas 17 Agustus 1945, Februari 2017 hal. 90-105

Ni Kadek Ariati dan I Wayan Suarbha, "Perlindungan Hukum Terhadap Konsumen Dalam Melakukan Transaksi Online", Kertha Semaya: Journal Ilmu Hukum, Volume 5, No. 1 2017

Ni Nyoman Ari Diah Nurmantari dan Nyoman A. Martana, "Perlindungan Hukum Terhadap Data Pribadi Peminjam Dalam Layanan Aplikasi Pinjaman Online", Kertha Wicara, Volume 8 Nomor 12 November 2019

Padma Widyantari dan Adi Sulistiyono, "Pelaksanaan Harmonisasi Rancangan Undang- Undang Perlindungan Data Pribadi (RUU PDP)", Jurnal Privat Law, Volume 8, No. 1 Januari-Juni 2020, hal. 117-123

Sandryones Palinggi dan Erich C. Limbongan, "Pengaruh Internet Terhadap Industri ECommerce Dan Regulasi Perlindungan Data Pribadi Pelanggan di Indonesia", disampaikan pada Seminar Nasional Riset dan Teknologi (SEMNAS RISTEK), Januari 2020, hal. 225-232

Sinta Dewi Rosadi, "Implikasi Penerapan Program E-Health Dihubungan Dengan Perlindungan Data Pribadi", Arena Hukum, Volume 9, Nomor 3 Desember 2016, hal. 403-420

Sulistiyono Padma, A. W. (2020). Pelaksanaan Harmonisasi Rancangan Undang-Undang Perlindungan Data Pribadi (Ruu Pdp). Jurnal Privat Law, VIII(Vol 8, No 1 (2020): JANUARIJUNI), 117-123. https://jurnal.uns.ac.id/privatlaw/article/view/40384

Wahyu Hanggoro Suseno. 2008. “Kontrak Perdagangan Melalui Internet (Electronic Commerce) 
Ditinjau Dari Hukum Perjanjian”. Skripsi. Fakultas Hukum, Universitas Sebelas Maret, Surakarta.

Wicipto Setiadi, Iwan Joeseof Erar, dan Muhammad Helmi Fahrozi. "Pemberdayaan Masyarakat Dalam Mengimplementasikan Nilai Pancasila Untuk Menghadapi Globalisasi dan Era Industri 4.0". Jurnal Papatung, Volume 3, Nomor 1, Tahun 2020, hal. 63

\section{Sumber Lainnya}

Agus Tri Haryanto, “APJII Sebut Jumlah Pengguna Internet di Indonesia Naik Saat Pandemi”, https://inet.detik.com/telecommunication/d-5194182/apjii-sebut-jumlah-penggunainternet-di-indonesia-naik-saat-pandemi diakses 30 Oktober 2020

Antara dan Kodrat Setiawan, "Bank Indonesia: Transaksi E-Commerce Agustus 2020 Naik hingga Mencapai 140 Juta", https://bisnis.tempo.co/read/1398066/bank-indonesiatransaksi-e-commerce-agustus-2020-naik-hingga-mencapai-140-juta/full\&view=ok diakses 30 Oktober 2020

Bernadetha Aurelia Oktavira, "Dasar Hukum Perlindungan Data Pribadi Pengguna Internet”, https://www.hukumonline.com/klinik/detail/ulasan/lt4f235fec78736/dasar-hukumperlindungan-data-pribadi-pengguna-internet/ diakses 4 November 2020

Cindy Mutia Annur, “Daftar Kejahatan Siber yang Paling banyak Dilaporkan ke Polisi”, https://databoks.katadata.co.id/datapublish/2020/09/08/daftar-kejahatan-siberyang-paling-banyak-dilaporkan-ke-polisi diakses pada 4 November 2020

Edmon Makarim, “Pertanggungjawaban Hukum Terhadap Kebocoran Data Pribadi”, https://www.hukumonline.com/berita/baca/lt5f067836b37ef/pertanggungjawabanhukum-terhadap-kebocoran-data-pribadi-oleh--edmon-makarim/ diakses 4 November 2020

Naskah Akademik Rancangan Undang-Undangan Perlindungan Data Pribadi Rancangan Undang-Undang Perlindungan Data Pribadi

Roy Franedya, "1,2 Juta Data Pengguna Dikabarkan Bocor, Bhinneka Minta Maaf", https://www.cnbcindonesia.com/tech/20200512164725-37-157971/12-juta-datapengguna-dikabarkan-bocor-bhinneka-minta-maaf, diakses tanggal 18 Oktober 2020 